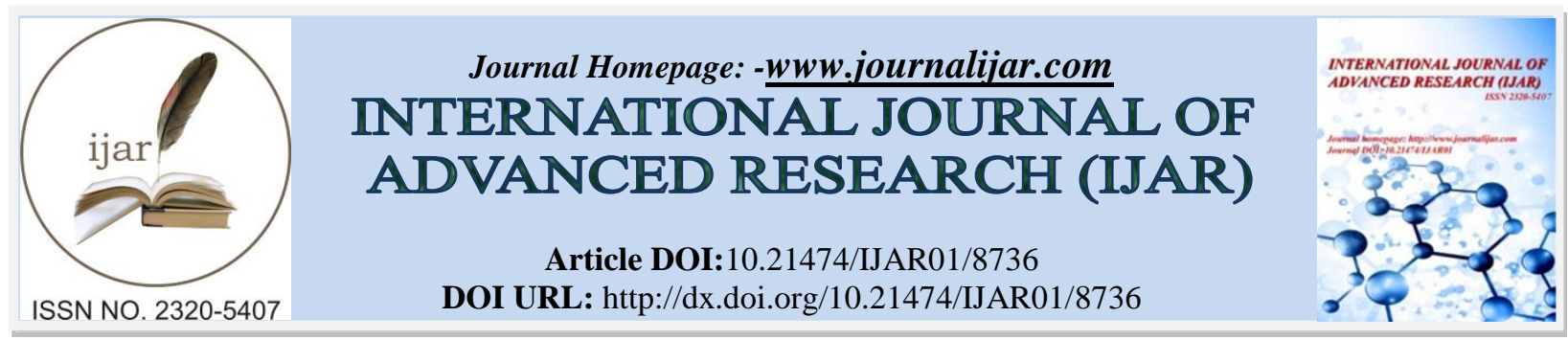

RESEARCH ARTICLE

\title{
ANALYTICAL METHOD DEVELOPMENT AND VALIDATION OF STABILITY INDICATING RP- HPLC METHOD FOR ESTIMATION OF AMLODIPINE BESYLATE AND CELECOXIB IN SYNTHETIC MIXTURE.
}

\author{
Ms. Seema Nitin Bhai Patel, Ms. Bhumi Rajdevbhai Patel and Sharda. \\ School of Pharmacy, Pethapur, Gandhinagar, Gujarat.
}

\section{Manuscript Info}

Manuscript History

Received: 18 January 2019

Final Accepted: 20 February 2019

Published: March 2019

Key words:-

Celecoxib,AmlodipineBesylate,Simultan eousEstimation,HPLCMethod,

Validation.

\section{Abstract}

A simple, rapid, economical, precise and accurate HPLC method for simultaneous estimation of Celecoxib and Amlodipine Besylate in their combined dosage form has been developed.

A Stability indicating reverse phase high performance liquid chromatographic method was developed for the simultaneous estimation of Celecoxib and Amlodipine Besylate in their combined dosage form. The separation was achieved by LC- 20 AT C18 $(250 \mathrm{~mm}$ x $4.6 \mathrm{~mm}$ x

$2.6 \mu \mathrm{m}$ ) column and Buffer (Potassium Phosphate, $\mathrm{pH}$ 4.5): Methanol $(85: 15)$ at a flow rate of $1 \mathrm{ml} / \mathrm{min}$. Detection was carried out at $240 \mathrm{~nm}$. Retention time $4.080 \mathrm{~min}$ and 5.343 for Celecoxiband AmlodipineBesylaterespectively.Themethodhasbeenvalidatedforlinearit $\mathrm{y}$, accuracy and precision. Linearity observed for Celecoxib 20-60 $\mu \mathrm{g} / \mathrm{ml}$ and for Amlodipine Besylate 1-3 $\mu \mathrm{g} / \mathrm{ml}$. Developed method was found to be accurate, precise and rapid for simultaneousestimationofCelecoxibandAmlodipineBesylateintheircomb ineddosageform. The proposed method was successfully applied for the simultaneous estimation of both the drugs in commercial Combined dosageform.

The drug was subjected to stress condition of hydrolysis, oxidation, photolysis and Thermal degradation, Considerable Degradation was found in Thermal degradation. The proposed method was successfully applied for the simultaneous estimation of both the drugs in commercial Combined dosage form.

Copy Right, IJAR, 2019,. All rights reserved.

\section{Introduction:-}

Amlodipine besylate(AML) 3-ethyl 5-methyl 2-[(2-aminoethoxy)methyl]-4-(2-chlorophenyl)- 6-methyl-1,4dihydropyridine-3,5-dicarboxylate-benzene sulfonic acid is potent dihydro Calcium channel blocker Antihypertensive drug.Various analytical methods have been reported for the assay of AML alone or in combination with other Pharmaceutical Formulations. 


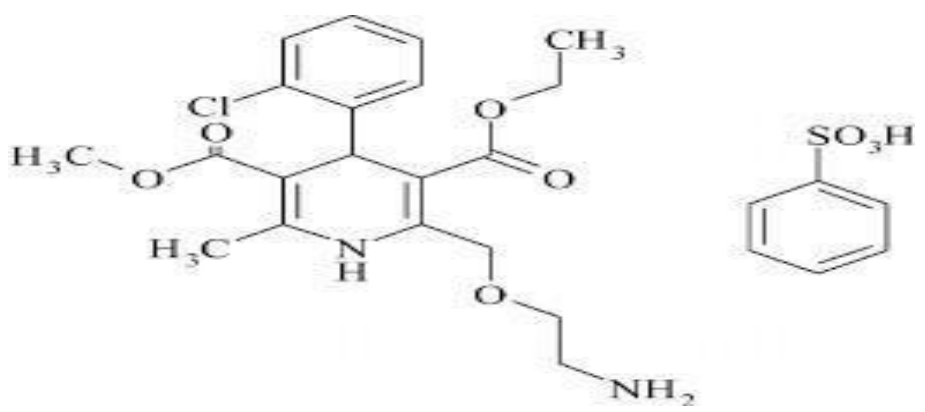

Fig 1:-Structure of Amlodipine besylate

Celecoxib (CEL)4-[5-(4-Methylphenyl)-3-(trifluoromethyl)pyrazol-1-yl]benzenesulfonamide is Nonsteroidal antiinflammatory drug.Various analytical methods have been reported for the assay of CEL alone or in combination with other PharmaceuticalFormulations.

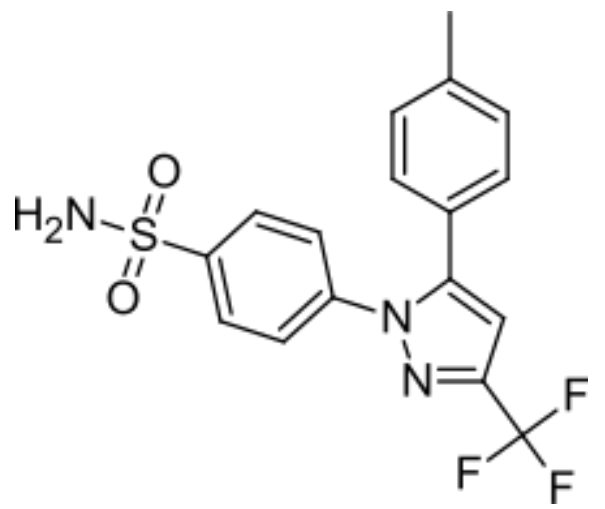

Fig 2:-Structure of Celecoxib

Both Drugs are official in IP and BP. Literature survey revealed that there are several methodswerereportedfortheestimationofAMLandCELindividually.Asnoanalytical method is available for their simultaneous estimation, however, it is essential to develop a suitableanalyticalmethodforsimultaneousestimationofAMLandCELinbulkand in pharmaceutical preparations, because HPLC methods have been widely used for routine quality control assessment of drugs, because of their accuracy, repeatability, selectivity, sensitivityandspecificity.Wehavedevelopedasimple,precise,accurateandspecificRP- HPLC method for the simultaneous estimation of AML and CEL in bulk and in pharmaceutical dosage forms. Because analytical methods must be validatebefore use by the pharmaceutical industry, the proposed HPLC- UV detection method was validated in accordance with International conference in Harmonization (ICH)[10] guidelines,byassessingitsselectivity, linearity,accuracy,andprecision,limit ofdetection and limitofquantification.

\section{Materials And Methods:-}

\section{Reagents and Chemical}

Amlodipine besylate and Celecoxib were procured from Prudence pharmachem Ankles war, Gujarat, India. The market. HPLC grade reagents methanol, acetonitrile (Merck specialists pvt, Ltd Mumbai) were used for study. All the reagent prepared by carbon dioxide free water and whereas the sample solution prepared in carbon dioxide free water double Distilled water for HPLC Purpose.

\section{Apparatus and chromatographic conditions}

HPLC method development and validation was done on a HPLC instrument(LC 20AT) PDA detector, Stationary Phase used was C18 Hypersil BDS, 250 x $4.6 \mathrm{~mm}, 5 \mu$ column particle size and mobile phase consisting of Buffer,

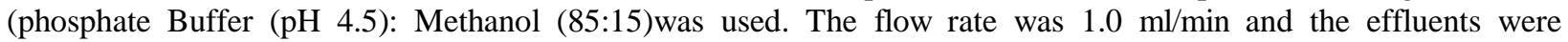
monitored at $240 \mathrm{~nm}$. The mobile phase was filtered through nylon $0.45 \mu \mathrm{m}$ membrane filter (Millipore Pvt., Ltd, Bangalore, India). Injection volume was $20 \mu \mathrm{L}$. All weighing were done on analytical balance. 


\section{Preparation of mobile phase}

The mobile phase was prepared with accurately weighed 6.8 gm of Potassium dihydrogen Ortho phosphate in a $1000 \mathrm{ml}$ of Volumetric flask added about $900 \mathrm{ml}$ of milli-Q water and degas to sonicated and finally make up the $\begin{array}{llllll}\text { volume with } \quad \text { water then } & \text { adjusted } & \text { to } & \text { with }\end{array}$ dil.Orthophosphoricacidsolution.Bufferandmethanoltakenintheratio85:15.Themobile phase was degassed for 15 minutes beforeuse.

\section{Preparation of Standard solutions}

Amlodipine Besylate standard stock solution: (2 ppm)

A $20 \mathrm{mg}$ of Amlodipine Besylate was weighed and transferred to a $100 \mathrm{~mL}$ volumetric flask. volume was made up to the mark with diluent. Take $10 \mathrm{ml}$ from this Solution and transfer to $100 \mathrm{ml}$ Volumetric flask and Volume was made up with the diluent.Take $1 \mathrm{ml}$ from this solution and transferred int0 $10 \mathrm{ml}$ volumetric flask and volume made up with the diluent.

\section{Celecoxib standard stock solution: (40 ppm)}

A $40 \mathrm{mg}$ of Celecoxib was weighed and transferred to a $100 \mathrm{~mL}$ volumetric flask and Volume made up with the diluent.Take $1 \mathrm{ml}$ from this solution and transferred int $010 \mathrm{ml}$ volumetric flask and volume made up with the diluent.

\section{Preparation of Sample solutions}

Take weigh of powder sample equivalent to $20 \mathrm{mg}$ AML and $400 \mathrm{mg}$ CEL and transferred into $100 \mathrm{ml}$ volumetric flask. Sonicated the solution for $30 \mathrm{~min}$ with few $\mathrm{ml}$ of diluent. Take $10 \mathrm{ml}$ from above solution and transferred into $100 \mathrm{ml}$ vol.flask make up to mark with diluent.

\section{Result And Discussion:-}

Method validation

The method was validated according to International Conference on Harmonization guidelines for validation of analytical procedures.

To evaluate the linearity of the method, six different dilutions were made from the standard stock solutions in the working range of 1-3 ppm and 20-60 ppm for Amlodipine besylate and Celecoxib respectivey.

In order to determine the accuracy of the method, three different concentrations $(80 \%, 100 \%$ and $120 \%)$ of tablet formulation were used and their recovery was calculated. Regarding the determination of the precision (repeatability) five replicate injections of the working standard Amlodipine besylate and Celecoxib were injected and the relative standard deviation (RSD) of the peak areas were calculated for the replicate injections. To determine the LOD and LOQ, serial dilutions of the combination were made from the standard stock solution the signal from the samples was compared with those of blank samples.

\section{System suitability}

As per USP-24, system suitability tests were carried out on freshly prepared standard stocksolutionofAmlodipinebesylateandCelecoxibunderoptimizedchromatographic condition and parameters were studied to evaluate the suitability of the system.Results are shownTable.1

Table.1 System suitability testing

\begin{tabular}{|l|l|l|}
\hline Parameters & Amlodipine Besylate & Celecoxib \\
\hline Retention time (min) & & 4.080 \\
\hline Theoretical plate & 3343 & 7180 \\
\hline Tailing factor & 1.264 & 1.385 \\
\hline Resolution & 4.505 & \\
\hline
\end{tabular}

\section{Linearity and Range}

The linearity for Amlodipine Besylate and Celecoxib were assessed by analysis of combined standard solution in range of $1-3 \mu \mathrm{g} / \mathrm{ml}$ and $20-60 \mu \mathrm{g} / \mathrm{ml}$ respectively into $100 \mathrm{ml}$ volumetric flaskandmakeupwithmobilephase.Correlationcoefficientfor calibrationcurveAmlodipine Besylate and Celecoxib was found to be 0.999 and 0.999 respectively. 
Table 2:-Linearity data for Amlodipine Besylate

\begin{tabular}{|l|l|l|}
\hline Sr. No & Concentration $(\boldsymbol{\mu g} / \mathbf{m l})$ & Area \\
\hline 1 & 1 & 102.27 \\
\hline 2 & 1.5 & 147.49 \\
\hline 3 & 2 & 202.41 \\
\hline 4 & 2.5 & 251.36 \\
\hline 5 & 3 & 306.01 \\
\hline
\end{tabular}

Table 3:-Linearity data for Celecoxib

\begin{tabular}{|l|l|l|}
\hline Sr. No & Concentration $(\boldsymbol{\mu g} / \mathbf{m l})$ & Area \\
\hline 1 & 20 & 510.871 \\
\hline 2 & 30 & 735.164 \\
\hline 3 & 40 & 1008.459 \\
\hline 4 & 50 & 1251.952 \\
\hline 5 & 60 & 1507.440 \\
\hline
\end{tabular}

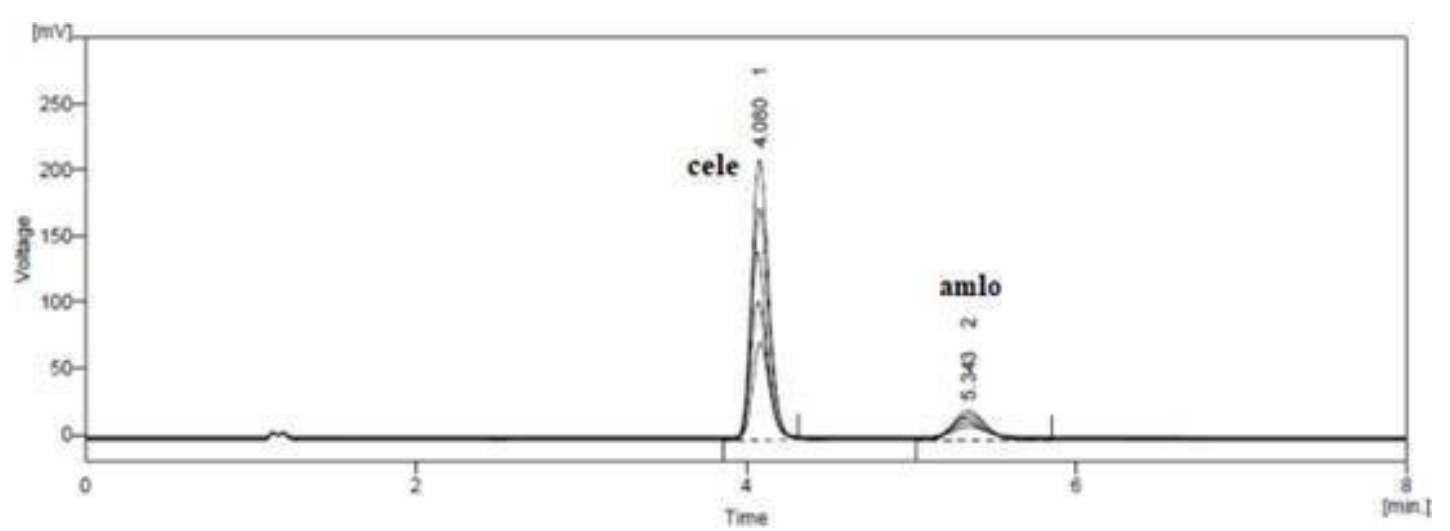

Fig 3:-Overlay chromatogram of different concentrations of mixtures of Amlodipine Besylate and Celecoxib

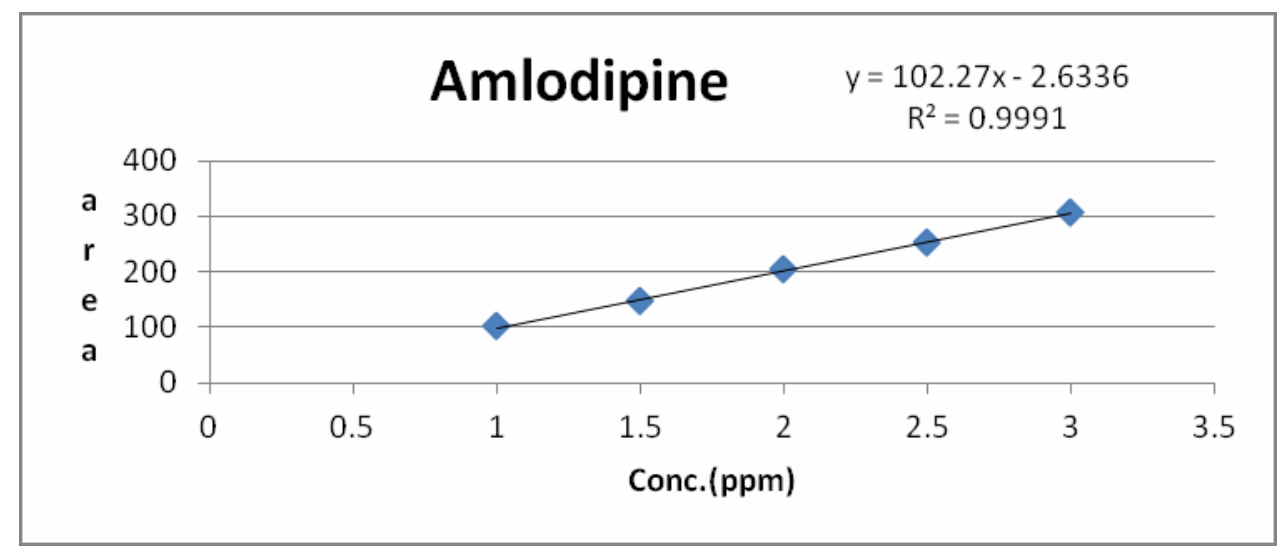

Fig 4:-Calibration Curve of Amlodipine Besylate (1-3 ppm) 


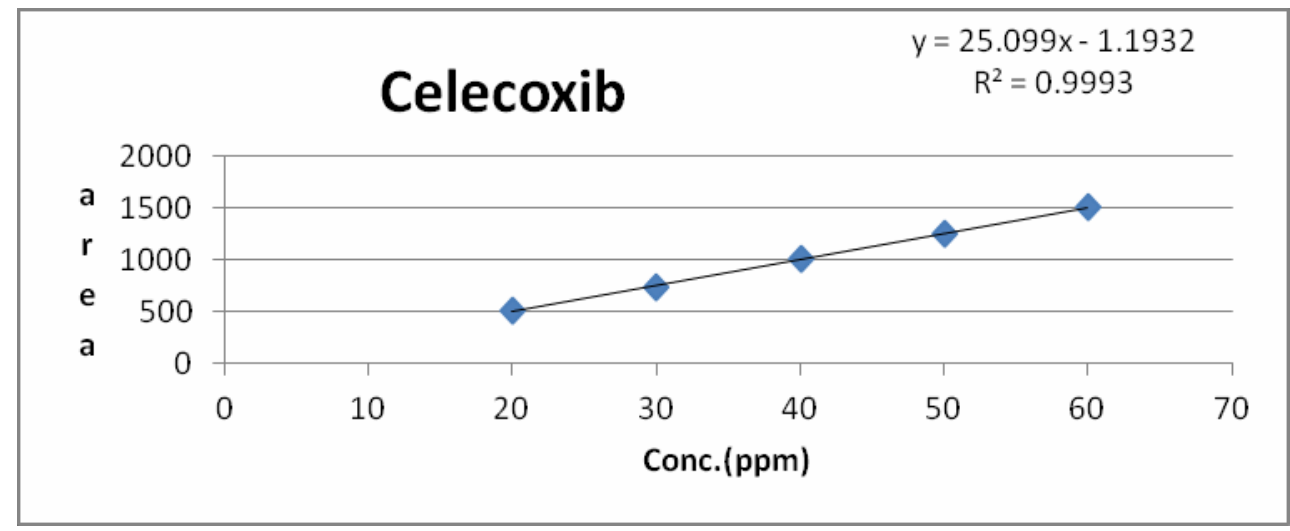

Accuracy

Fig 5:-Calibration Curve of Celecoxib (20-60 ppm)

Accuracy was determined by recovery studies of Amlodipine besylate and Celecoxib, known amount of standard was added to the preanalysed sample and subjected to the proposed HPLC analysis. Results of recovery study are shown in Table 4 \& 5. The study was done at three different concentration levels.

Table 4:-Recovery data for Amlodipine Besylate

\begin{tabular}{|c|c|c|c|c|c|c|}
\hline SR. NO. & $\begin{array}{l}\text { Conc. } \\
\text { Level (\%) }\end{array}$ & $\begin{array}{l}\text { Sample } \\
\text { Amount }\end{array}$ & $\begin{array}{l}\text { Amount } \\
\text { Added }\end{array}$ & $\begin{array}{l}\text { Amount } \\
\text { recovered } \\
(\mu \mathrm{g} / \mathrm{ml})\end{array}$ & $\begin{array}{l}\% \\
\text { Recovery }\end{array}$ & $\begin{array}{l}\text { \% Mean Recovery } \pm \\
\text { S.D }\end{array}$ \\
\hline 1 & \multirow{3}{*}{$80 \%$} & 1 & 0.8 & 0.807 & 100.823 & \multirow{3}{*}{$100.383 \pm 0.973$} \\
\hline 2 & & 1 & 0.8 & 0.808 & 101.058 & \\
\hline 3 & & 1 & 0.8 & 0.794 & 99.268 & \\
\hline 4 & \multirow{3}{*}{$100 \%$} & 1 & 1 & 1.001 & 100.122 & \multirow{3}{*}{$100.937 \pm 1.205$} \\
\hline 5 & & 1 & 1 & 1.023 & 102.321 & \\
\hline 6 & & 1 & 1 & 1.004 & 100.367 & \\
\hline 7 & \multirow{3}{*}{$120 \%$} & 1 & 1.2 & 1.213 & 101.048 & \multirow{3}{*}{$100.388 \pm 0.594$} \\
\hline 8 & & 1 & 1.2 & 1.203 & 100.219 & \\
\hline 9 & & 1 & 1.2 & 1.199 & 99.896 & \\
\hline
\end{tabular}

Table 5:-Recovery data for Celecoxib

\begin{tabular}{|c|c|c|c|c|c|c|}
\hline SR. NO. & $\begin{array}{l}\text { Conc. } \\
\text { Level }(\%)\end{array}$ & $\begin{array}{l}\text { Sample } \\
\text { amount } \\
(\mu \mathrm{g} / \mathrm{ml})\end{array}$ & $\begin{array}{l}\text { Amount } \\
\text { Added } \\
(\mu \mathrm{g} / \mathrm{ml})\end{array}$ & $\begin{array}{l}\text { Amount } \\
\text { recovered } \\
(\mu \mathrm{g} / \mathrm{ml})\end{array}$ & $\begin{array}{l}\% \\
\text { Recovery }\end{array}$ & $\begin{array}{l}\% \text { Mean Recovery } \\
\pm \text { S.D }\end{array}$ \\
\hline 1 & \multirow[b]{3}{*}{$80 \%$} & 20 & 16 & 16.194 & 101.214 & \multirow[b]{3}{*}{$100.312 \pm 1.191$} \\
\hline 2 & & 20 & 16 & 16.122 & 100.762 & \\
\hline 3 & & 20 & 16 & 15.834 & 98.962 & \\
\hline 4 & \multirow{3}{*}{$100 \%$} & 20 & 20 & 19.963 & 99.814 & \multirow{3}{*}{$100.889 \pm 0.948$} \\
\hline 5 & & 20 & 20 & 20.249 & 101.247 & \\
\hline 6 & & 20 & 20 & 20.321 & 101.606 & \\
\hline 7 & \multirow{3}{*}{$120 \%$} & 20 & 24 & 24.179 & 100.747 & \multirow{3}{*}{$101.296 \pm 0.663$} \\
\hline 8 & & 20 & 24 & 24.488 & 102.032 & \\
\hline 9 & & 20 & 24 & 24.266 & 101.109 & \\
\hline
\end{tabular}

\section{Precision}

The precision (repeatability) of an analytical method refers to the use of the analytical procedure within a laboratory over a short period of time using the same analyst with the same equipment and is expressed as the \% RSD. The precision study (Table $\quad \mathbf{6} \quad \boldsymbol{\&} \quad 7$ ) showed thatmethod hasagoodreproducibilitywhichwasapprovedbythe analysisoffivereplicate injections of the working standardsolutions. 
Table 6:-Repeatability data for Amlodipine Besylate

\begin{tabular}{|c|c|c|c|c|}
\hline \multicolumn{5}{|c|}{ Amlodipine Besylate } \\
\hline Sr No. & Conc $(\mu \mathrm{g} / \mathrm{ml})$ & Area & Mean \pm S.D $(n=6)$ & $\%$ R.S.D \\
\hline \multirow{6}{*}{1.} & \multirow{6}{*}{2} & 203.033 & \multirow{6}{*}{$202.592 \pm 1.118$} & \multirow{6}{*}{0.552} \\
\hline & & 202.648 & & \\
\hline & & 200.811 & & \\
\hline & & 202.615 & & \\
\hline & & 202.200 & & \\
\hline & & 204.242 & & \\
\hline
\end{tabular}

Table 7:-Repeatability data for Celecoxib

\begin{tabular}{|c|c|c|c|c|}
\hline \multicolumn{5}{|c|}{ Celecoxib } \\
\hline Sr No. & Conc $(\mu \mathrm{g} / \mathrm{ml})$ & Area & Mean \pm S.D $(n=6)$ & $\%$ R.S.D \\
\hline \multirow{6}{*}{1.} & \multirow{6}{*}{40} & 1011.478 & \multirow{6}{*}{$1008.689 \pm 6.710$} & \multirow{6}{*}{0.665} \\
\hline & & 1009.442 & & \\
\hline & & 996.977 & & \\
\hline & & 1009.389 & & \\
\hline & & 1007.360 & & \\
\hline & & 1017.485 & & \\
\hline
\end{tabular}

\section{Intraday Precision}

Standard solution containing $(20,40,60 \mu \mathrm{g} / \mathrm{ml})$ of Celecoxib and $(1,2,3 \mu \mathrm{g} / \mathrm{ml})$ of Amlodipine Besylate were analyzed three times on the same day and \% R.S.D was calculated.

Table 8:-Intraday precision data for estimation of Amlodipine Besylate

\begin{tabular}{|c|c|c|c|}
\hline & \multicolumn{3}{|c|}{ Amlodipine Besylate } \\
\hline SR. NO. & $\begin{array}{l}\text { Conc. } \\
(\mu \mathrm{g} / \mathrm{ml})\end{array}$ & $\begin{array}{l}\text { Area } \\
\text { Mean } \pm \text { S.D. }(n=3)\end{array}$ & \% R.S.D \\
\hline 1 & 1 & $101.769 \pm 0.177$ & 0.174 \\
\hline 2 & 2 & $203.844 \pm 1.446$ & 0.709 \\
\hline 3 & 3 & $301.321 \pm 3.841$ & 1.274 \\
\hline
\end{tabular}

Table 9:-Intraday precision data for estimation of Celecoxib

\begin{tabular}{|l|l|l|l|}
\hline & Celecoxib & \% R.S.D \\
\hline SR. NO. & $\begin{array}{l}\text { Conc. } \\
(\boldsymbol{\mu g} / \mathbf{m l})\end{array}$ & $\begin{array}{l}\text { Area } \\
\text { Mean } \pm \text { S.D. }(\mathbf{n}=\mathbf{3})\end{array}$ & 0.476 \\
\hline 1 & 20 & $507.460 \pm 2.414$ & 0.432 \\
\hline 2 & 40 & $1020.596 \pm 4.406$ & 0.312 \\
\hline 3 & 60 & $1510.421 \pm 4.710$ & \\
\hline
\end{tabular}

\section{Interday precision}

Standard solution containing $(20,4060 \mu \mathrm{g} / \mathrm{ml})$ of Celecoxib and (1,2,3 $\mu \mathrm{g} / \mathrm{ml})$ of Amlodipine Besylate were analysed three times on the different day and \% R.S.D was calculated.

Table 10:-Interday precision data for estimation of Amlodipine Besylate

\begin{tabular}{|l|l|l|l|}
\hline & Amlodipine Besylate & \% R.S.D \\
\hline SR. NO. & $\begin{array}{l}\text { Conc. } \\
(\boldsymbol{\mu g} / \mathbf{m l})\end{array}$ & $\begin{array}{l}\text { Area } \\
\text { Mean } \pm \text { S.D. }(\mathbf{n}=\mathbf{3})\end{array}$ & 1.888 \\
\hline 1 & 1 & $101.345 \pm 1.913$ & 1.057 \\
\hline 2 & 2 & $199.053 \pm 2.104$ & 0.300 \\
\hline
\end{tabular}


Table 11:-Interday precision data for estimation of Celecoxib

\begin{tabular}{|l|l|l|l|}
\hline & Celecoxib & \% R.S.D \\
\hline SR. NO. & $\begin{array}{l}\text { Conc. } \\
(\boldsymbol{\mu g} / \mathbf{m l})\end{array}$ & $\begin{array}{l}\text { Area } \\
\text { Mean } \pm \text { S.D. }(\mathbf{n}=\mathbf{3})\end{array}$ & 0.858 \\
\hline 1 & 20 & $509.291 \pm 4.371$ & 1.231 \\
\hline 2 & 40 & $990.636 \pm 12.191$ & 0.470 \\
\hline 3 & 60 & $1516.091 \pm 7.122$ & \\
\hline
\end{tabular}

\section{Limit of detection and Limit of Quantification}

Thedetectionlimitor LODisthelowest amountofanalyteinasamplethatcanbedetectedItmay be expressed as a concentration that gives a signal to noise ratio of approximately 3:1. While the Quantification limit or LOQ is the lowest amount of analyte in a sample that can be determined with acceptable precision and accuracy with a signal to noise ratio of approximately 10:1 can be takenasLOQofthe.Our methodshowedthe(LOD)forAmlodipineandCelecoxibwere foundto be $0.092 \mu \mathrm{g} / \mathrm{ml}$ and $1.557 \mu \mathrm{g} / \mathrm{mlrespectivelyandTheLOQvaluesforAmlodipineandCelecoxib} \mathrm{were} \mathrm{found} 0.278 \mu \mathrm{g} / \mathrm{ml}$ and $4.717 \mu \mathrm{g} / \mathrm{mlrespectively.}$

\section{Robustness}

The robustness of the proposed method was evaluated by slight modification in the mobile phase compostion, Flow rate and $\mathrm{pH}$ values of the mobile phase. During these studies it was found that there was not much change retention time, area andsymmetry ofpeak.Thedeveloped methodwasusedfortheassayofcommerciallyavailabletablets and six replicate determinations were performed. The interference of excipients was studied by comparing the chromatography of standards and formulations. The same shape and retention times of peaks showed that there was no interference from excipients.

\section{Force degradation study}

Forced degradation studies were performed to evaluate the stability indicating properties and specificity of the method. Intentional degradation was carried out by exposing of samples to stability condition $1 \mathrm{~N} \mathrm{HCl}$ at $600 \mathrm{C} 90$ min, $0.5 \mathrm{~N} \mathrm{NaOH}$ at60 ${ }^{0} \mathrm{C} 90 \mathrm{~min}, 3 \% \mathrm{H} 2 \mathrm{O} 2$ at $25{ }^{0} \mathrm{C}$ for $6 \mathrm{hrs}, 110^{0} \mathrm{C}$ for $3 \mathrm{hrs}$ and UV 18 hrs. They were then analysed againstcontrol.

\begin{tabular}{|l|l|l|}
\hline Drugs & Retention time(min) & Area $(\mathbf{m V} . \mathbf{s})$ \\
\hline Amlodipine Besylate & 5.033 & 188.104 \\
\hline Celecoxib & 3.753 & 916.253 \\
\hline
\end{tabular}

Table 12:-Amlodipine Besylate \% Degradation

\begin{tabular}{|l|l|l|l|l|}
\hline Amlodipine Besylate & \multicolumn{4}{l|}{} \\
\hline Parameter & Standard & Sample & \%Degradation \\
\hline & Area & \%Degradation & Area & 18.592 \\
\hline Acid & 150.515 & 19.983 & 153.131 & 22.649 \\
\hline Base & 155.049 & 17.573 & 145.500 & 13.288 \\
\hline Thermal & 158.013 & 15.997 & 163.108 & 20.752 \\
\hline Oxidation & 152.928 & 18.700 & 149.068 & \\
\hline
\end{tabular}

Table 13:-Celecoxib \% Degradation

\begin{tabular}{|l|l|l|l|l|}
\hline Photo & 152.282 & 19.044 & 153.976 & 18.143 \\
\hline Celecoxib & Standard & \%Degradation & Sample & Area \\
\hline Parameter & Area & 12.803 & 787.870 & \% Degradation \\
\hline & 798.943 & 27.719 & 682.565 & 14.012 \\
\hline Acid & 662.278 & 30.291 & 619.163 & 25.505 \\
\hline Base & 638.708 & 18.196 & 738.145 & 32.424 \\
\hline Thermal & 749.528 & 10.970 & 806.221 & 19.439 \\
\hline Oxidation & 815.743 & & & 12.009 \\
\hline Photo & & & \\
\hline
\end{tabular}




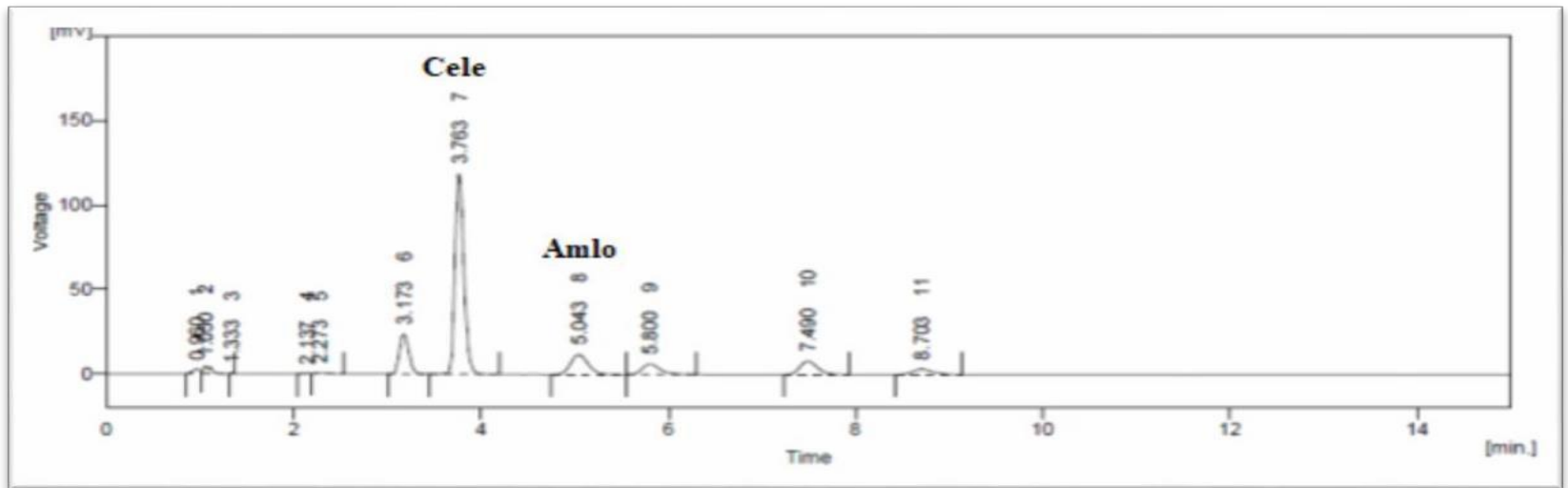

Fig 6:-Amlodipine besylate and Celecoxib Acid Degradation Sample at $60^{\circ} \mathrm{C}$ for $90 \mathrm{~min}$

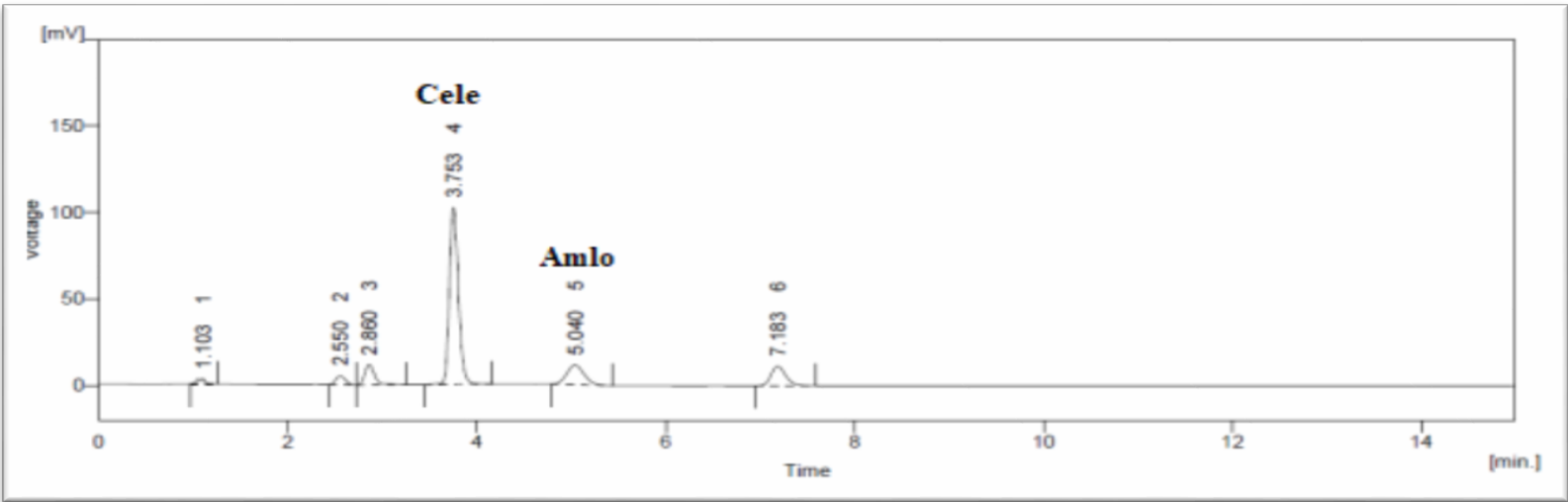

Fig 7:-Amlodipine Besylate and Celecoxib Base Degradation Sample at $60^{\circ} \mathrm{C}$ for $90 \mathrm{~min}$

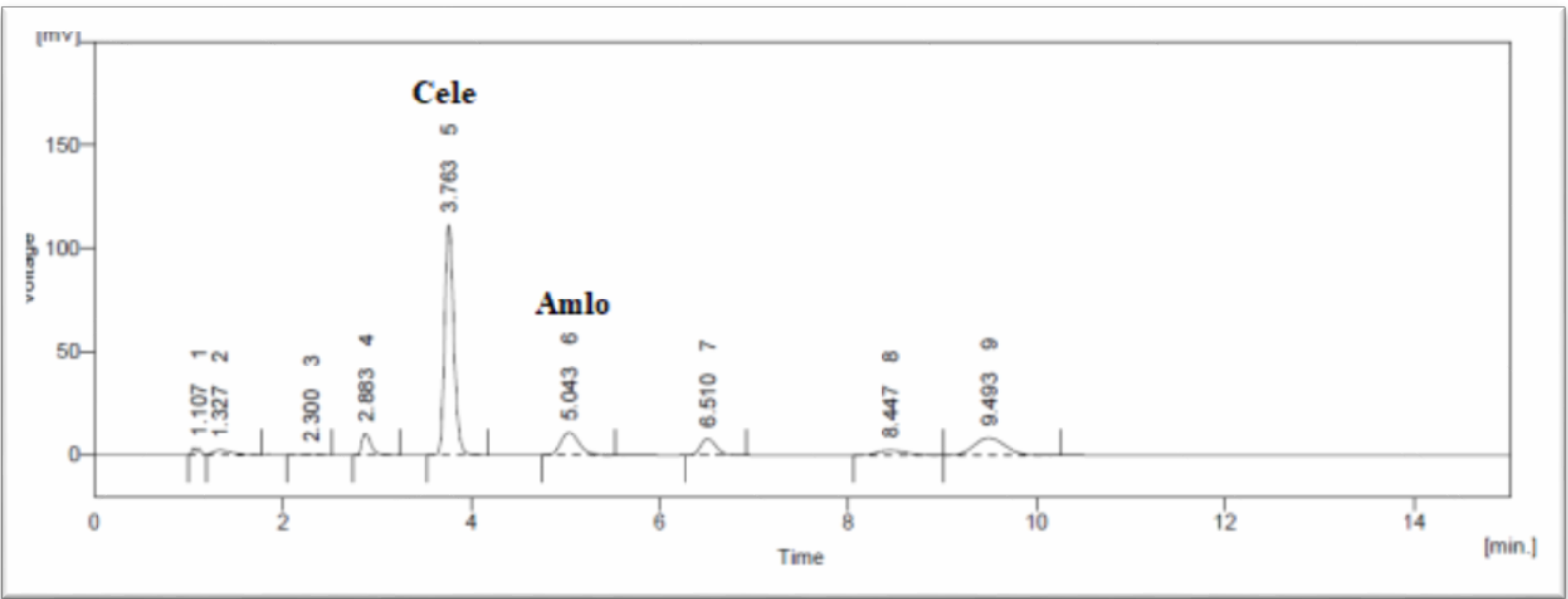

Fig 8:-Amlodipine Besylate and Celecoxib Oxidation Degradation sample in 3\% $\mathrm{H}_{2} \mathrm{O} 2$ at Room temperature for 6 hrs 


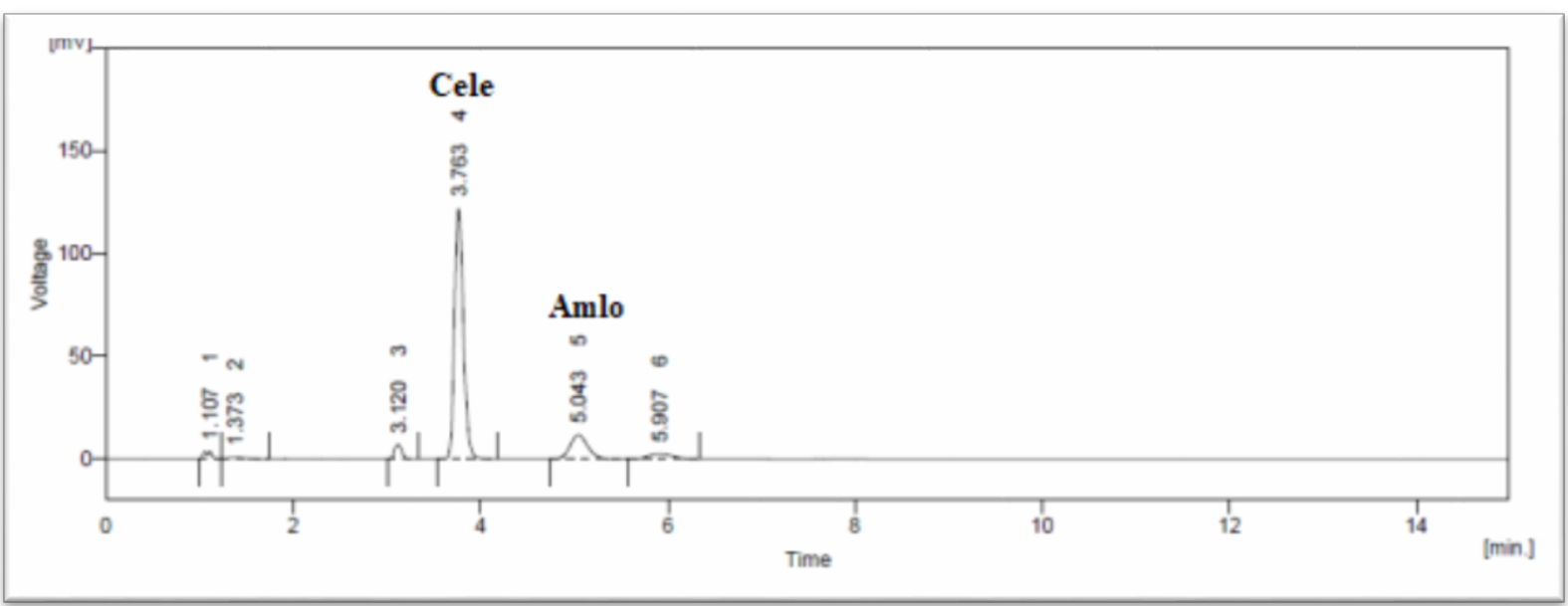

Fig 9:-Amlodipine Besylate and Celecoxib Photo Degradation sample at 254nm UV light (18hrs)

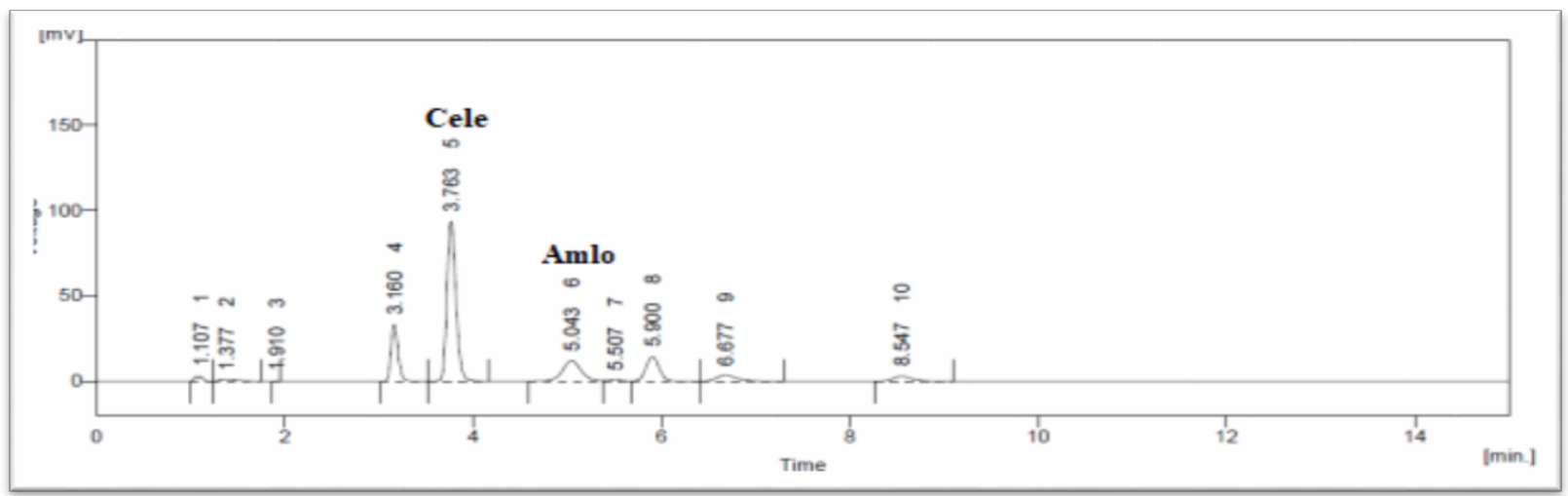

Fig. 10:-Amlodipine Besylate and Celecoxib Thermal Degradation sample at $110^{0} \mathrm{C}$ for $3 \mathrm{hrs}$

\section{Conclusion:-}

A simple, specific, accurate and precise Stability indicating RP-HPLC method has been developed and validated as per ICH guideline for Simultaneous Estimation of Celecoxib and Amlodipine Besylate in their combined dosage form.Validation parameters like Linearity, Accuracy, Precision, Robustness, Systemsuitability, Specificityweretested. Observationofall these parameters leads to the point that developed Stability indicating RP-HPLC method is linear, accurate, precise, specific and robust. It can be successfully adopted for routine quality control analysis of Celecoxib and Amlodipine Besylate in Combined dosage formwithout any interference from common excipients and impurity.This method can now transfer to utilize for routine laboratory analysis and assay of Celecoxib and Amlodipine Besylate in their combined dosageform.

\section{Acknowledgment:-}

Author are thankful to the principal, Sharda school of pharmacy for providing necessary facilities to carry out the experiment. 


\section{References:-}

1. Watson DG. Pharmaceutical Analysis; 2 Ed Edn; Elsevier Churchill, Livingstone, 2005, pp 87-88,267-268.

2. Christian GD. In: Analytical Chemistry; 4 th Edn; John Wiley and Sons, United Kingdom, 1986, pp 1-6.

3. ICH, Validation of Analytical Procedures; Methodology, Q2 (R1),International Conference on Harmonization, IFPMA, Geneva1996.

4. "Drug profile for Amlodipine", Aug.-2018,www.drugbank.ca/salts/DBSALT001054

5. "Drug profile for Celecoxib", Aug.-2018,www.drugbank.ca/drugs/DB08822

6. IndianPharmacopoeia2018,Government ofIndia,Ministryofhealthandfamilywelfare, ghaziyabad,pp1224-1225.

7. British Pharmacopoeia 2015, The department of health, social services and public safety, London, Amlodipinemonograph.

8. Hussain MF, Bhadra S, Kumar U, Rouf SS "The ICH guidance in practice: Stress degradation studies on aceclofenac and development of a validated stability-indicating reversed-phaseHPLCassayintabletdosageform", Derpharmachemica,2013,5(4),131- 146. 